Петрунина Ж. В.

Z. V. Petrunina

«ЕВРАЗИЙСКАЯ ИНИЦИАТИВА» ПАК КЫН ХЕ: ЕЩЁ ОДИН СПОСОБ АКТИВИЗАЦИИ СОЦИАЛЬНО-ЭКОНОМИЧЕСКОГО РАЗВИТИЯ ДАЛЬНЕГО ВОСТОКА РОССИИ

\title{
PARK GEUN-HYE «EURASIAN INITIATIVE»: ONE MORE WAY OF ACTIVATING SOCIOECONOMIC DEVELOPMENT OF THE RUSSIAN FAR EAST
}

Петрунина Жанна Валерьяновна - доктор исторических наук, профессор кафедры истории государства и права Комсомольского-на-Амуре государственного технического университета (Россия, Комсомольск-на-Амуре); 681013, Комсомольск-на-Амуре, пр. Ленина, 27; 8(4217)24-11-58. E-mail: petrunina71@bk.ru.

Ms. Zanna V. Petrunina - Doctor of History, Professor, Department of State and Law History, Komsomolsk-on-Amur State Technical University (Russia, Komsomolsk-on-Amur); 681013, Komsomolsk-onAmur, 27, Lenin Str.; 8(4217)24-11-58. E-mail: petrunina71@bk.ru.

Аннотация. В октябре 2013 г. лидер Республики Корея Пак Кын Хе выдвинула проект «Евразийская инициатива». Проект направлен на интеграцию стран Азии и Европы и на создание условий для урегулирования Корейской проблемы. В реализации «Евразийской инициативы» планируется участие России, которая занимает выгодное географическое положение. Участие России позволит активизировать социально-экономическую жизнь на Дальнем Востоке России, задействовать российские дальневосточные территории в международном экономическом сотрудничестве, сохранить квалифицированные кадры в регионе. В статье проанализированы позитивные тенденции расширения торгово-экономического сотрудничества между Дальним Востоком России и государствами Корейского полуострова: увеличение объёмов товарооборота, развитие инфраструктуры российских портов и транспортных путей. Выявлены факторы, затрудняющие реализацию проекта «Евразийская инициатива».

Summary. In October 2013, the leader of the Republic of Korea Park Geun-Hye advanced the project «Eurasian Initiative». The project is oriented at the integration of Asian and European countries and at creating favourable conditions for the settlement of the Korean problem. Russia was invited to take part in implementation of the «Eurasian Initiative», as it has a favorable geographical location. Russia's participation will enhance the socioeconomic life of the Russian Far East; involve Russian Far East territories in international economic cooperation, preserve qualified personnel in the region. The article analyses the positive trend of expanding trade and economic cooperation between the Russian Far East and the states of the Korean Peninsula: an increase in the volume of trade, infrastructure development of Russian ports and trans-tailors routes. The article identified factors that make it difficult to implement the project «Eurasian Initiative».

Ключевые слова: Шёлковый путь, Евразийская инициатива, транспортные коммуникации, Корейский полуостров, Дальний Восток России.

Key words: the Silk Road, Eurasian Initiative, transportation lines, Korean Peninsula, Russian Far East.

УДК 93/94

Осенью 2013 г. лидерами Республики Корея (РК) и Китайской Народной Республики были выдвинуты инициативы, направленные на объединение стран Азиатско-Тихоокеанского региона (АТР) со странами Европы в единое экономическое пространство. «Евразийская инициатива» президента РК Пак Кын Хе направлена на создание «Одного континента», «Креативного континента» и «Мирного континента». При реализации этого проекта президент РК рассчитывает, во-первых, на расширение экономической и логистической интеграции стран Азии и Европы, а во-вторых, не имея иного сухопутного сообщения с континентом, кроме как через территорию КНДР, на создание благоприятных условий для урегулирования Корейской про- 
Петрунина Ж. В.

«ЕВРАЗИЙСКАЯ ИНИЦИАТИВА» ПАК КЫН ХЕ: ЕЩЁ ОДИН СПОСОБ АКТИВИЗАЦИИ

СОЦИАЛЬНО-ЭКОНОМИЧЕСКОГО РАЗВИТИЯ ДАЛЬНЕГО ВОСТОКА РОССИИ

блемы, в решение которой были бы вовлечены заинтересованные государства региона. В основе проекта «Экономический пояс Шёлкового пути», предложенного председателем КНР Си Цзиньпином, лежит задача активизировать торгово-экономическое и инвестиционное сотрудничество Китая со странами Центральной, Восточной, Южной и Западной Азии. По мнению президента Исследовательского центра развития Госсовета КНР Ли Вэя, «китайская инициатива “Экономический пояс Шёлкового пути” будет играть решающую роль в улучшении глобальной экономической ситуации в мире, связывая мировые рынки и формируя новый мировой порядок для экономического развития» [1]. При этом независимо от вариантов и механизмов претворения этого проекта приоритетом Пекина является ускорение реформ и экономическое развитие западных провинций КНР (провинций Цинхай, Шэньси, Ганьсу и двух автономных районов - Синьцзян-Уйгурского и Нинся-Хуэйского). Азиатские лидеры заявляют, что при реализации выдвинутых проектов улучшится мировой экономический климат, будут созданы условия для динамичного сотрудничества между регионами.

Корейский и китайский проекты не исключают участия России, для которой РК и КНР входят в число наиболее перспективных партнёров в АТР. Современный уровень российско-китайских отношений характеризуется политической элитой стран как «отношения партнёрства и взаимодействия» [2], а отношения между Китаем и Южной Кореей, пройдя путь от «дружбы и совместных отношений» (1992 г.) к «полномасштабному совместному партнёрству» $(1998$ г.) и «всестороннему совместному партнёрству» $(2003$ г.) [3, 28], в настоящее время вышли на уровень «стратегического сотрудничества и партнёрства».

Приветствуя стремление сторон к политическому и экономическому сотрудничеству, российское общество неоднозначно оценило инициативы руководителей РК и КНР. Особую озабоченность общественности Дальнего Востока России вызвал тот факт, что в рамках «Экономического пояса Шёлкового пути» транспортные магистрали ориентированы преимущественно на Запад. В перспективе это может привести к сокращению участия российского Дальнего Востока в мировых интеграционных процессах, что замедлит и без того низкие темпы социально-экономического развития региона. В этой ситуации к выдвинутой Пак Кын Хе «Евразийской инициативе» стоит присмотреться пристальнее, поскольку этот проект представляет интерес как для Дальнего Востока России, так и для РК и КНР. Развитие отношений с РК актуализируется и в связи с созданием на российском Дальнем Востоке ТОСЭР.

Одним из важных направлений активизации экономического сотрудничества является развитие транспортных коммуникаций. Идея объединения в единую транспортную сеть железных дорог России, государств Корейского полуострова и стран Европы получила развитие в начале XXI в. и с того времени неизменно находилась в фокусе внимания российских политиков и лидеров обоих государств Корейского полуострова [4, 462 - 463]. В течение первых лет XXI в. сторонами был подписан ряд соглашений о сотрудничестве, заложивших основу для трёхстороннего соглашения по строительству Транскорейской железнодорожной магистрали, которая должна была через Хасан соединиться с Транссибом. Наряду с очевидными экономическими выгодами (удешевление перевозок и сокращение времени доставки грузов из Азии в Европу до 20 суток против 45 дней по морскому маршруту; экономическое развитие Дальнего Востока России; привлечение дополнительных грузопотоков на Транссиб и снижение нагрузки на порты Хабаровского и Приморского краёв, задействованных в перевалке угля и испытывающих недостаток перевозных мощностей), эксплуатация единой железнодорожной магистрали решает для России и внешнеполитическую задачу её присутствия в АТР и укрепления международного сотрудничества.

Инициатива Пак Кын Хе ориентирована на то, чтобы сделать Южную Корею интегрированной частью континента, и соответствует задачам, поставленным президентом РФ В. В. Путиным и направленным на развитие российского Дальнего Востока. Особое значение в реализации плана, намеченного Пак Кын Хе, придаётся незамерзающему северокорейскому порту Раджин, который расположен в 56 км от границы с Россией (см. прим. 1). С 2013 г., 
после того как была введена в эксплуатацию первая очередь проекта Транскорейской магистрали на участке Хасан (РФ) - Туманган (КНДР) - Раджин (КНДР), объёмы торгово-экономического сотрудничества Дальнего Востока России с РК увеличились. По данным Дальневосточного таможенного управления РФ, в 2014 г. товарооборот между ДВФО и РК составил 10228 млн долл., что на 3,4 \% больше по сравнению с 2013 г. В 2015 г. объём российского дальневосточного экспорта в Южную Корею составил 5824,02 млн долл., а импорт 430,818 млн долл. РК входит в первую тройку основных торговых партнёров ДВФО. Объём товарооборота ДВФО с КНДР определить сложно. В 2014 г. товарооборот между РФ и КНДР составил 92,3 млн долл. Торговый оборот между ДВФО и КНДР пока составляет менее $1 \%$ указанных данных. В 2015 г. экспорт российского Дальнего Востока в Северную Корею составил 10,86 млн долл., в то время как северокорейский импорт - около 2 млн долл. [5].

Несмотря на положительную динамику торговых отношений между государствами, способствующую экономическому развитию дальневосточных территорий России и КНДР, следует признать, что эти цифры ничтожно малы по сравнению с советским периодом. Пока КНДР занимает 113-е место среди внешнеторговых партнёров РФ (доля в обороте - 0,01\%). Россия находится на третьем месте в списке импортёров в КНДР (доля - 1,5 \%) [6]. Однако страны намерены расширять сотрудничество. По мнению главы Министерства по развитию Дальнего Востока А. Галушки, фактором ускорения развития сотрудничества послужат особые экономические зоны, создаваемые на территории обоих государств [7].

К позитивным аспектам следует отнести и то, что эксплуатация порта Раджин позволит, не теряя объёмов поставок, приступить к постепенной модернизации портов Дальнего Востока, переваливающих уголь (порт Посьет и порт Восточный (Приморский край), порт Ванино и Ванинский балкерный терминал (Хабаровский край)).

Политика России по обеспечению железнодорожного сообщения с государствами Корейского полуострова не противоречит интересам Китая. С марта 2014 г. по Транссибу через порт Раджин российская ОАО «РЖД Логистика» осуществляла доставку угля с разрезов Кузбасса в порты КНР (Шанхай, Лянюньгань, Гуаньчжоу). Китай испытывает потребность в угле как главном виде топлива для выработки электроэнергии в восточных и юго-восточных провинциях. Присутствие на китайском рынке российского угля позволяет России сохранять рынки сбыта и выдерживать острую конкурентную борьбу с другими поставщиками этого сырья (например, Австралией). Китаю же выгодно приобретать уголь из России в силу географической близости государств и наличия между странами прямого железнодорожного сообщения, что значительно снижает стоимость поставляемого сырья. Наряду с Китаем потребность в российском угле испытывают Япония и Южная Корея.

Являющаяся ключевым союзником КНДР на мировой арене КНР выступает за соединение Транскорейской и Транссибирской железнодорожных магистралей, преследуя и собственные цели. Представители китайского бизнеса ещё в 2008 г. арендовали причал в северокорейском порту Раджин и провели его реконструкцию. Наладив транспортно-логистическую линию к порту от китайского г. Хуньчунь, в перспективе Пекин рассчитывал на соединение транспортных коммуникаций Северо-Восточного Китая с портом Раджин. В этом случае Китай получил бы возможность осваивать восточное побережье Северной Кореи, приобрёл бы ещё один выход к морским путям АТР, а железнодорожная ветка оказалась бы включена в Евразийский транспортный коридор.

Несмотря на то что страны АТР понимают значимость инициативы Пак Кын Хе, существует ряд факторов, сдерживающих реализацию «Евразийской инициативы». Прежде всего, политика КНДР, проводимая в регионе, по мнению лидеров многих государств, неприемлема для возобновления диалога с Пхеньяном. В феврале 2016 г. Северной Кореей в нарушение резолюций Совета Безопасности ООН с космодрома «Сохэ» на побережье Жёлтого моря была запущена ракета «Кванмёнсон» с одноимённым спутником [8]. Это было воспринято мировым сообществом как провокация. В ответ на запуск спутника Северной 
Петрунина Ж. В.

«ЕВРАЗИЙСКАЯ ИНИЦИАТИВА» ПАК КЫН ХЕ: ЕЩЁ ОДИН СПОСОБ АКТИВИЗАЦИИ

СОЦИАЛЬНО-ЭКОНОМИЧЕСКОГО РАЗВИТИЯ ДАЛЬНЕГО ВОСТОКА РОССИИ

Кореей Южная Корея вышла из трёхстороннего соглашения по строительству Транскорейской железнодорожной магистрали, которая должна была соединить оба государства с Россией. Решением этого вопроса может стать изменение формата экономического взаимодействия, расширенного до четырёхстороннего (включая КНР).

Значительное влияние на осуществление «Евразийской инициативы», складывание трёхсторонних экономических связей оказывает КНР, политики которой решительно настроены на реализацию проекта «Экономический пояс Шёлкового пути» и внимательно следят за тенденциями развития отношений между Россией и государствами Корейского полуострова, стараясь не выпускать ситуацию из-под своего контроля.

Таким образом, в современных реалиях, когда остро ощущается потребность сокращения времени доставки и удешевления транспортировки грузов от производителей к рынкам сбыта, соединение Транссибирской и Транскорейской железных дорог представляет собой перспективный проект, позволяющий соединить между собой Восточную Азию и Европу. В условиях стремления России развивать свои дальневосточные территории и действия международных экономических санкций реализация «Евразийской инициативы» может способствовать снижению напряжения между Россией и странами АТР, занимающими неоднозначную позицию в отношении РФ под давлением мировых лидеров, но не сбрасывающими со счетов и собственные интересы. Отказ от реализации проекта по соединению Транскорейской и Транссибирской железнодорожных магистралей способен не только сдерживать развитие Дальнего Востока России, но и сохранить напряжённость на международной арене. В этих условиях политикам задействованных государств важно подняться над противоречиями и сосредоточится на решении практических задач.

\section{ЛИТЕРАТУРА}

1. China Daily. October 30. 2015. P. 12.

2. Медведев: российско-китайские отношения находятся на высоком уровне [Электронный ресурс] // TACC: информационное агентство России, 15.12.2015. - Режим доступа: http://tass.ru/politika/2529187 (дата обращения 21.04. 2016).

3. Петрунина, Ж. В. Эволюция отношений между Китаем и Южной Кореей на рубеже XX-XXI веков / Ж. В. Петрунина // Вестник Рязанского государственного университета им. С. А. Есенина. - 2012. № 35. - C. 27-37.

4. Petrunina Z. V., Chibisova O. V. Russian Far East in the system of transportation links between Europe and Asia // Mediterranean Journal of Social Sciences. - 2015. - T. 6, № 6. - P. 460-464.

5. Статистическая информация о внешней торговле за 4 квартал 2015 г. [Электронный ресурс] // Официальный сайт Дальневосточного таможенного управления Федеральной таможенной службы. Режим доступа: http://dvtu.customs.ru/index.php?option=com content\&view=article\&id=18715:-4-2015\&catid=63:stat-vnesh-torg-cat\&Itemid=282 (дата обращения 21.04.2016).

6. «Хасан - Раджин»: железная дорога отменяется? [Электронный ресурс] // Информационное агентство Патрнер.Ру. - Режим доступа: http://www.rzd-partner.ru/news/zheleznodorozhnaiainfrastruktura/khasan---radzhin---zheleznaia-doroga-otmeniaetsia/ (дата обращения 21.04.2016).

7. Объём торговли России и КНДР может вырасти до $\$ 1$ млрд. [Электронный ресурс] // ВВС. Русская служба. 27.04.2015. - Режим доступа: http://www.bbc.com/russian/rolling_news/2015/04/150427 rn_korea_russia_trade (дата обращения 21.04.2016).

8. КНДР отчиталась об успешном запуске ракеты со спутником [Электронный ресурс] // РБК. 07.02.2016. - Режим доступа: http://www.rbc.ru/politics/07/02/2016/56b6bc9e9a79476ee581de0e (дата обращения 21.04.2016).

\section{ПРИМЕЧАНИЯ}

1. Глубина акватории порта составляют 11,5 м и обеспечивает приём судов дедвейтом до 40 тыс. т, длина причальной линии терминала 480 м. Мощности комплекса позволяют переваливать до 4 млн т грузов в год. Суммарная единовременная вместимость склада 200 тыс. т. Суточная норма погрузки на судно - до 14 тыс. т, в зависимости от дедвейта судна. 